Nota

\title{
DESENVOLVIMENTO DE PLÂNTULAS DE LIMOEIRO 'CRAVO’ RELACIONADO A POSIÇÃO DE SEMEADURA
}

\author{
Walter Geremias Rodriguez Robles ${ }^{1 *}$; Paulo Sérgio Rodrigues de Araújo; Keigo Minami² \\ ${ }^{1}$ Pós-Graduandos do Depto. de Produção Vegetal - USP/ESALQ. \\ 2 Depto. de Produção Vegetal - USP/ESALQ, C.P. 9 - CEP: 13418-900 - Piracicaba, SP. \\ *Autor correspondente <wgrroble@carpa.ciagri.usp.br>
}

RESUMO: Instalou-se um ensaio em casa de vegetação com o objetivo de relacionar a posição da semente e o desenvolvimento de plântulas de limoeiro 'Cravo'. Foram semeadas nas três prováveis posições que a semente tomaria ao ser lançada ao solo ou substrato: 1) deitada; 2) ápice para cima e 3) ápice para baixo. Este experimento foi realizado em bandejas de poliestireno expandido com 128 células, utilizando-se como substrato a mistura de vermiculita expandida e material orgânico vegetal. Adotou-se o delineamento experimental em blocos ao acaso, com 4 repetições e 40 sementes por parcela (1 semente/célula). Aos 75 dias após à semeadura, observou-se maior quantidade de plântulas com raízes normais quando colocadas as sementes nas posições deitada e ápice para baixo. A posição ápice para cima apresentou maior quantidade de plântulas com raízes tortas e enoveladas. O comprimento do sistema radicular foi aproximadamente o dobro da parte aérea, independente da posição da semente, ocorrendo o inverso em relação à massa da matéria seca.

Palavras-chave: Citrus limonia, desenvolvimento radicular, enovelamento, raiz

\section{DEVELOPMENT OF RANGPUR LIME SEEDLINGS IN RELATION TO SOWING POSITION}

\begin{abstract}
This experiment was conducted in a green house, with the objective of relating the position of Rangpur Lime seed to the development of seedlings. Seeds were sown in the three probable positions that they would take when planted in the soil or substratum: 1) sideways; 2) apex upwards and 3) apex downwards. The experiment was performed in plastic trays of expanded poliestirene speedlings with 128 cells filled with the substratum mixture of expanded vermiculite and vegetable organic material. The adopted experimental design used randomized blocks, with 4 replicates and 40 seeds per plot ( 1 seed/cell). At 75 days of sowing, a larger amount of seedlings with normal roots was observed when seeds are placed are on the side and apex down positions. The position apex upwards presented larger amount of seedlings with crooked and reeled roots. The length of the root system was almost the double of the aerial part, independent of the position of the seed, ocurring the inverse in relation to the mass of the dry matter.

Key words: Citrus limonia, development roots, reeled roots
\end{abstract}

\section{INTRODUÇÃO}

A muda cítrica com formação normal deve apresentar um bom sistema radicular, com raiz principal longa e reta, provida de abundantes raízes secundárias e radicelas. Deve-se evitar raízes enoveladas ou excessivamente tortuosas. A haste da parte aérea deve ser reta com 60 a $65 \mathrm{~cm}$ de altura, sustentando 3-4 ramos que saem dos últimos $15 \mathrm{~cm}$ (Gomes, 1973).

O sistema tradicional de produção de portaenxertos de citros é feita inicialmente em sementeiras de solo, colocando-se em média 30 a $40 \mathrm{~cm}^{3}$ de sementes por metro linear de sulco ou 1,5 litros por 10 $\mathrm{m}^{2}$ (Moreira \& Donadio, 1968; Prates \& Bonin, 1986). Recomenda-se empregar de duas a quatro vezes mais sementes que o número de porta-enxertos a produzir, o que possibilita uma seleção mais rigorosa por ocasião da repicagem, pela necessidade de descarte de grande quantidade de plântulas defeituosas ou fracas (Webber e Montenegro, citados por Piza Junior, 1966; Teófilo Sobrinho, 1991).

Moreira \& Donadio (1968) montaram um ensaio para estudar a formação de plântulas com raízes tortas e enoveladas, pressupondo que a posição da semente no solo fosse a causa principal. Os autores concluíram que o maior número de plântulas com raízes tortas ocorreram na posição com "ápice para cima", enquanto que na posição com "ápice para baixo", originaram maior número de plântulas normais.

Teófilo Sobrinho (1991) ressalta que os portaenxertos podem ser produzidos efetuando-se a sementeira em bandejas, melhorando o manejo da semente por ocasião da semeadura.

Segundo Tessarioli Neto (1995), as bandejas usadas na produção de mudas de hortaliças são de plástico ou de poliestireno expandido, este apresentando a vantagem de possuir um melhor efeito isolante térmico, 
o que permite um melhor desenvolvimento das mudas. Essas bandejas podem ser usadas para produção de porta-enxertos em ambientes controlados, seguindo-se o transplantio para embalagens individuais, como vasos ou sacos plásticos (Penteado, 1995).

Tessarioli Neto (1995) recomenda que as bandejas devem ser colocadas no interior das casas de vegetação apoiadas em suportes que permitam a passagem do ar e da luz na parte de baixo das bandejas, de modo a proporcionar uma poda natural do sistema radicular das mudas.

A produção de porta-enxertos em bandejas ou outros recipientes apresenta também a vantagem de melhor pegamento no transplantio, uma vez que este é feito com o "torrão" sem danos ou exposição do sistema radicular. Por outro lado, há uma maior dificuldade na observação de anormalidades, como o enovelamento de raízes o que justifica ainda mais o estudo para diminuir a ocorrência deste problema.

Neste trabalho avaliou-se o efeito da posição das sementes no substrato sobre a germinação e desenvolvimento de plântulas de limoeiro 'Cravo', quando semeadas em bandejas.

\section{MATERIAL E MÉTODOS}

O experimento foi conduzido de abril a junho de 1996 em casa de vegetação, com estrutura tipo arco, cobertura de plástico transparente de 150 micra e laterais revestidas de tela (sombrite de 50\%), no Departamento de Produção Vegetal, da Escola Superior de Agricultura "Luiz de Queiroz", em Piracicaba-SP.

Os frutos maduros de limoeiro 'Cravo' (Citrus limonia Osbeck) foram colhidos de plantas da coleção do referido Departamento. Os frutos foram seccionados, sendo extraídas as sementes, que foram lavadas em água corrente até completa extração da mucilagem. Foram secadas em camada única sobre folhas de jornal, colocadas em ambiente sombreado e arejado por 48 horas.

Utilizaram-se bandejas de poliestireno expandido $(680 \times 340 \times 120 \mathrm{~mm})$ com 128 células e como substrato o produto comercial Plantmax, composto de mistura de vermiculita expandida e material orgânico de origem vegetal, de natureza física farelado e capacidade de retenção de água mínima de 200 \% em massa. Após a seleção das sementes, procedeu-se a semeadura, colocando-se uma semente por célula. Foi utilizado o sistema de irrigação por aspersão, com regime diário de três vezes, com duração de 15 minutos cada.

$O$ delineamento experimental utilizado foi o de blocos casualizados com três tratamentos (semente na posição deitada, com ápices para cima e para baixo), em quatro repetições, perfazendo 12 parcelas, sendo cada uma constituída por 40 sementes, considerando-se para avaliação 18 plântulas centrais por parcela.

A percentagem de germinação foi avaliada 35 dias após da semeadura. Os parâmetros de comprimentos da parte aérea e da raiz principal, desenvolvimento do sistema radicular (raízes normais, raízes tortas e raízes enoveladas) e massa da matéria seca da parte aérea e raízes, foram avaliados aos 75 dias após a semeadura.

Os valores obtidos da porcentagem de germinação de limoeiro 'Cravo', em relação a posição da semente no substrato, foram transformados utilizando-se arc sen $(\mathrm{x} / 100)^{0,5}$. Quanto ao número de plântulas de limoeiro 'Cravo' com raízes normais, tortas e enoveladas, os dados encontrados foram transformados utilizando-se $(x+0,5)^{0,5}$.

Os resultados tiveram suas médias comparadas através do teste de Tukey a 0,05 de probabilidade estatística.

\section{RESULTADOS E DISCUSSÃO}

Os valores médios observados para percentual de germinação, altura $(\mathrm{cm})$ da parte aérea, comprimento $(\mathrm{cm})$ da raiz principal, massa $(\mathrm{g})$ da matéria seca da parte aérea e raízes e número de plântulas com raízes normais, tortas e enoveladas estão apresentadas na TABELA 1.

Observa-se que, independente da posição da semente no substrato, a germinação foi superior a $84 \%$, não apresentando diferença significativa.

TABELA 1 - Percentual de germinação de sementes (aos 35 dias), parâmetros biométricos e qualidade do sistema radicular (75 dias após semeadura) de plântulas de limoeiro 'Cravo', em relação à posição da semente no substrato. ESALQ, Piracicaba-SP, 1996.

\begin{tabular}{|c|c|c|c|c|c|c|c|c|}
\hline \multirow[t]{2}{*}{$\begin{array}{l}\text { Posição de } \\
\text { semente }\end{array}$} & \multirow[t]{2}{*}{ Germinação } & \multicolumn{2}{|c|}{ Parte Aérea } & \multicolumn{2}{|c|}{ Raízes } & \multicolumn{3}{|c|}{$\begin{array}{l}\text { Número de plântulas com } \\
\text { raízes }\end{array}$} \\
\hline & & Comprimento & Massa & $\begin{array}{c}\text { Comprimento raiz } \\
\text { principal }\end{array}$ & $\begin{array}{l}\text { Massa seca } \\
\text { total }\end{array}$ & Normais & Tortas & Enoveladas \\
\hline & $(\%)$ & $(\mathrm{cm})$ & $\sec a(g)$ & $(\mathrm{cm})$ & $(\mathrm{g})$ & & & \\
\hline Deitada & $86,27 \mathrm{a}$ & $4,59 \mathrm{ab}$ & $0,47 a$ & $7,94 \mathrm{a}$ & $0,20 a$ & $3,34 \mathrm{a}$ & $2,41 \mathrm{~b}$ & $0,84 \mathrm{~b}$ \\
\hline $\begin{array}{l}\text { Ápice para } \\
\text { cima }\end{array}$ & $87,94 \mathrm{a}$ & $4,27 \mathrm{~b}$ & $0,52 \mathrm{a}$ & $8,52 \mathrm{a}$ & $0,23 \mathrm{a}$ & $1,05 b$ & $3,60 \mathrm{a}$ & $1,84 \mathrm{a}$ \\
\hline $\begin{array}{l}\text { Ápice para } \\
\text { baixo }\end{array}$ & $84,82 \mathrm{a}$ & $5,13 \mathrm{a}$ & $0,50 \mathrm{a}$ & $7,92 \mathrm{a}$ & $0,18 \mathrm{a}$ & $2,98 \mathrm{a}$ & $2,61 b$ & $0,97 b$ \\
\hline CV (\%) & 10,05 & 5,92 & 18,76 & 8,68 & 17,77 & 12,29 & 15,60 & 16,06 \\
\hline
\end{tabular}

Médias seguidas de letras iguais na vertical, não diferem pelo teste de Tukey a $5 \%$. 
Quanto ao comprimento da parte aérea, destacou-se a posição da semente com ápice para baixo, não diferindo entretanto da posição deitada, que foi semelhante à posição com ápice para cima.

Os parâmetros comprimento da raiz principal e massas da matéria seca tanto da parte aérea e das raízes não apresentaram diferença estatística entre os tratamentos avaliados. Ressalta-se que o comprimento da raiz principal foi aproximadamente o dobro da parte aérea, independente da posição, tendo ocorrido o inverso entre massa da matéria seca da parte aérea em relação às raízes.

Observa-se ainda na TABELA 1, que em relação às plântulas com raízes normais, as posições de semente deitada e ápice para baixo não diferiram entre si, embora tenham sido superiores a posição com ápice para cima. Nas plântulas com raízes tortas e enoveladas nota-se que a posição da semente com ápice para cima, diferiu significativamente das posições deitada e com ápice para baixo, ratificando os resultados encontrados em sementeira de solo por Moreira \& Donadio (1968).

\section{CONCLUSÕES}

- O comprimento do sistema radicular do limoeiro 'Cravo' foi aproximadamente o dobro da parte aérea, independentemente da posição da semente no substrato das bandejas, sendo que o inverso ocorreu em relação à massa da matéria seca.
- Constatou-se maior percentual de plântulas com raízes normais nas posições de sementes deitada e com ápice para baixo, enquanto tortas e enoveladas, na posição com ápice para cima.

\section{REFERÊNCIAS BIBLIOGRÁFICAS}

GOMES, P. Fruticultura brasileira. São Paulo: Nobel, 1973. 448p. MOREIRA, C.S.; DONADIO, L.C. Efeito da posição da semente de citros no tipo de seedling produzido. O Solo, v.40, p.69-70, 1968.

PENTEADO, S. R. Sistema de produção de mudas frutíferas e recipientes, embalagens e acondicionamento de mudas. In: MINAMI, K. Produção de mudas de alta qualidade em horticultura. São Paulo: T. A. Queiroz, 1995. cap.10, p.65-74.

PIZA JÚNIOR, C. de T. A formação da muda de citros. Campinas: Secretaria de Agricultura, Depto. da Produção Vegetal, 1966. 51p. (Boletim Técnico, 4).

PRATES, H.S.; BONIN, F.A. Formação da muda cítrica. Boletim Técnico, VI festa da laranja. 1986. 6p.

TEÓFILO SOBRINHO, J. Propagação dos citros, In: RODRIGUEZ, O.; VIÉGAS, F.; POMPEU, J.; AMARO, A. Citricultura brasileira. 2.ed. Campinas: Fundação Cargill, 1991. v.1, p.281-301.

TESSARIOLI NETO, J. Recipientes, embalagens e acondicionamentos de mudas de hortaliças. In: MINAMI, K. Produção de mudas de alta qualidade em horticultura. São Paulo: T.A. QUEIROZ, 1995. cap.9, p.59-64.

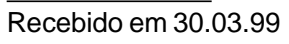

